Sris 3

(1832-1850)

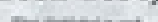

\section{On a new eudiometric process}

\section{Prof. Graham}

To cite this article: Prof. Graham (1846) On a new eudiometric process, Philosophical Magazine Series 3, 28:190, 566-566, DOI: 10.1080/14786444608645473

To link to this article: http://dx.doi.org/10.1080/14786444608645473

$$
\text { 册 Published online: } 30 \text { Apr } 2009 .
$$

Submit your article to this journal

LII Article views: 2

Q View related articles $\asymp$ 
cles. The crystallized sulphate of copper so obtained is often largely contaminated with sulphate of zinc, which may sometimes be seen in the form of slender white needles on the surface of the dark blue crystals, and in some of the applications of this salt may prove injurious. Sulphate of nickel, sulphate of lead, arsenic, and chlorides are also sometimes present.-From the Proceedings of the Chemical Society.

\section{ON A NEW EUdIOMETRIC PROCESS. BY PROF. GRAHAM.}

Professor Graham described a new eudiometric process for the rapid absorption of oxygen gas from atmospheric air and other gaseous mixtures containing oxygen. It consists in the employment of a solution in ammonia of a sulphite of the suboxide of copper and ammonia. This salt falls as a granular powder, when a stream of sulphurous acid gas is conveyed into a cold solution of the ammoniacal sulphate of copper. When dissolved in ammonia it absorbs oxygen with singular avidity, and when employed in this form in eudiometry gives results of considerable uniformity.-From the Proceedings of the Chemical Society.

\section{EQUIVALENT OF CHLORINE.}

M. Gerhardt observes, that M. Marignac has made some observations and experiments tending to show that the atomic weight of chlorine is not thirty-six times that of hydrogen, as he (M. Gerhardt) had concluded, but somewhat less. M. Marignac's conclusions are derived from the weight of chloride of potassium yielded by the calcination of chlorate of potash; to these results M. Gerhardt makes the following objections :-

It is the residue of chloride of potassium obtained, and not that of the oxygen gas, which is weighed; and from the following causes the quantity of chloride might be too small, and would diminish the atomic weight of chlorine:-a trace of moisture on the salt; a portion of chlorate or chloride carried off by the current of oxygen gas; if the oxygen were impure, and contained, as M. Marignac has stated, a trace of cblorine.

Thus, observes M. Gerhardt, all the errors which can be committed in these determinations are referrible to the chlorine, and give it in too small quantity.

From his experiments M. Gerhardt concludes, in opposition to those of M. Marignac, that the equivalents of chlorine, silver and potassium, are exact multiples of the equivalent of hydrogen, that is to say,-

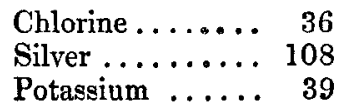

Journ. de Pharm. et de Ch., Avril 1846. 